\title{
Pesquisas clínicas e suas contribuições para a construção da evidência científica
}

\author{
Prof. Me. Joana Marcela Sales de Lucena ${ }^{\circledR}$
}

Pesquisas clínicas são estudos originais realizados com seres humanos com o objetivo de testar tratamentos, intervenções e/ou atestar modus operandi e comportamentos de populações específicas. Em geral, trazem a possibilidade de testar diversas hipóteses dentro de amplas possibilidades conforme sua validade interna e externa. A validade interna envolve o controle e planejamento do estudo de modo a minimizar ao máximo quaisquer erros oriundos do método aplicado; quanto maior o controle do ambiente clínico e das variáveis, maior a validade interna. Por exemplo, em um estudo clínico randomizado cujo objetivo foi avaliar os efeitos de um treino de marcha em solo e esteira com suporte parcial de peso corporal (SPPC), associados à fisioterapia convencional, sobre medidas de desfecho clínicofuncional em indivíduos pós-AVC, a amostragem em diferentes grupos de comparação foi aleatorizada de forma “cega”, os testes escolhidos refletiam o nível de locomoção e capacidade funcional adequadamente e o momento de aplicação (antes, durante e após a intervenção) indicam progressão da intervenção'. A aplicação dessas medidas somado à execução correta constroem uma boa validade interna para o estudo citado.

Considerando que o estudo apresenta boa validade interna, de forma que seus resultados são confiáveis, faz-se necessário verificar sua validade externa, a qual refere-se à possibilidade que o estudo tem de replicar seus resultados na mesma população em uma situação real. Um estudo que utiliza, por exemplo, 
métodos muito caros ou inacessíveis para

populações conhecidamente mais

carentes, embora com alta validade

interna podem ter baixa validade externa.

As pesquisas clínicas poderiam

ser classificadas em ordem de maior para

menor validade interna da seguinte

forma:

1. Ensaios clínicos randomizados

2. Estudos de caso controle

3. Estudos de coorte

4. Estudos transversais

5. Estudos observacionais

6. Estudos comunitários

Cada delineamento de estudo

trará suas particularidades. Um estudo

classificado como ensaio clínico

randomizado pode ser construído com

elementos que irão deixá-lo num nível de

controle de variáveis que o torna com alta

validade interna, como cegamento de

participantes e pesquisadores (estudo

duplo-cego) ou amplo controle de

variáveis, porém menor validade externa

na maioria dos casos. Já estudos

transversais observacionais de base populacional, por exemplo, evidenciam aspectos amplos e representativos de uma população em questão, embora dependam de como o pesquisador o conduziu para equilibrar sua alta validade externa sem perder o essencial na validade interna.

Independentemente do equilíbrio encontrado, as pesquisas clínicas constroem, tijolinho a tijolinho, um grande mural de evidências a serem angariados, tão logo que possível, por revisões sistemáticas e metanálises que poderão indicar a força da evidência científica.

$\overline{\text { Clinical research and its contributions to }}$ the construction of scientific evidence

Clinical researches are original studies carried out with human beings with the objective of testing treatments, interventions and / or attesting modus operandi and behaviors of specific populations. In general, they bring the possibility of testing several hypotheses within wide possibilities according to their internal and external validity. Internal 
validity involves the control and planning of the study in order to minimize as much as possible any errors arising from the applied method; the greater the control of the clinical environment and variables, the greater the internal validity. For example, in a randomized clinical study whose objective was to evaluate the effects of floor and treadmill walking with partial body weight support (SPPC), associated with conventional physical therapy, on measures of clinical-functional outcome in poststroke individuals , the sampling in different comparison groups was randomized "blindly", the tests chosen reflected the level of locomotion and functional capacity properly and the moment of application (before, during and after the intervention) indicates progression of the intervention1. The application of these measures in addition to the correct execution builds a good internal validity for the mentioned study.

Considering that the study has good internal validity, so that its results are reliable, it is necessary to verify its external validity, which refers to the possibility that the study has to replicate its results in the same population in a real situation. A study that uses, for example, very expensive or inaccessible methods for populations known to be in need, although with high internal validity may have low external validity.

Clinical trials could be ranked in order from highest to lowest internal validity as follows:

1. Randomized clinical trials

2. Case control studies

3. Cohort studies

4. Cross-sectional studies

5. Observational studies

6. Community studies

Each study design will bring its particularities. A study classified as a randomized clinical trial can be constructed with elements that will leave it with a level of control of variables that makes it with high internal validity, such as blinding of participants and researchers (double-blind study) or broad control of variables, however less external validity in most cases. Population-based observational crosssectional studies, for example, show broad 
and representative aspects of a population in question, although they depend on how the researcher conducted it to balance its high external validity without losing the essential internal validity.

Regardless of the balance found, clinical research builds, brick by brick, a large mural of scientific evidence to be obtained, as soon as possible, by systematic reviews and meta-analyzes that may indicate the strength of scientific evidence.

\section{\begin{tabular}{lllll}
\hline La & investigación & clínica & y & sus
\end{tabular} contribuciones a la construcción de evidencia científica}

Las investigaciones clínicas son estudios originales realizados con seres humanos con el objetivo de probar tratamientos, intervenciones y / o acreditar modus operandi y comportamientos de poblaciones específicas. En general, brindan la posibilidad de probar varias hipótesis dentro de amplias posibilidades de acuerdo con su validez interna y externa. La validez interna implica el control y la planificación del estudio con el fin de minimizar en la medida de lo posible los errores derivados del método aplicado; a mayor control del entorno clínico y de las variables, mayor validez interna. Por ejemplo, en un estudio clínico aleatorizado cuyo objetivo fue evaluar los efectos de la caminata en el piso y en cinta rodante con soporte parcial del peso corporal (SPPC), asociado con la fisioterapia convencional, sobre las medidas de resultado clínicofuncional en individuos que han sufrido un accidente cerebrovascular., el muestreo en los diferentes grupos de comparación fue aleatorizado "a ciegas", las pruebas elegidas reflejaron adecuadamente el nivel de locomoción y capacidad funcional y el momento de aplicación (antes, durante y después de la intervención) indica la progresión de la intervención1. La aplicación de estas medidas junto con la correcta ejecución construyen una buena validez interna para el estudio mencionado. Considerando que el estudio tiene buena validez interna, para que sus resultados sean confiables, es necesario verificar su validez externa, lo que se refiere a la posibilidad que tiene el estudio de replicar sus resultados en la misma población en una situación real. Un estudio 
que utiliza, por ejemplo, métodos muy costosos o inaccesibles para poblaciones que se sabe que lo necesitan, aunque con una alta validez interna puede tener una baja validez externa.

Los ensayos clínicos pueden clasificarse en orden de mayor a menor validez interna de la siguiente manera:

1. Ensayos clínicos aleatorizados

2. Estudios de casos y controles

3. Estudios de cohortes

4. Estudios transversales

5. Estudios de observación

6. Estudios comunitarios

Cada diseño de estudio aportará sus particularidades. Un estudio clasificado como ensayo clínico aleatorizado se puede construir con elementos que lo dejarán con un nivel de control de variables que lo haga con alta validez interna, como el cegamiento de participantes e investigadores (estudio doble ciego) o un amplio control de variables, sin embargo menor validez externa en la mayoría de los casos. Los estudios observacionales transversales de base poblacional, por ejemplo, muestran aspectos amplios y representativos de una población en cuestión, aunque dependen de cómo la realizó el investigador para equilibrar su alta validez externa sin perder la esencial validez interna.

Independientemente del equilibrio encontrado, la investigación clínica construye, ladrillo a ladrillo, un gran mural de evidencia científica que se obtendrá, lo antes posible, mediante revisiones sistemáticas y metaanálisis que puedan indicar la solidez de la evidencia científica.

\section{REFERÊNCIAS}

1. Boumer, T. C. et al . Efeitos do treino de marcha com Suporte parcial de peso corporal associado a fisioterapia convencional sobre o equilíbrio funcional e a independência da marcha pós-AVC: Estudo clínico randomizado. Revista Inspirar: Movimento e Saúde, v. 19, nº4, 2019.

Como citar esse editorial / How to cite this editorial:

Lucena, J. M. S. Pesquisas clínicas e suas contribuições para a construção da evidência científica. Arq. Bras. Ed. Fís., Tocantinópolis, v. 3, n. 2, Ago./Dez., p. 09 - 13, 2020. 